\title{
Strategies for dealing with sin in relation to poverty
}

\author{
Kakwata, Frederick N \\ North-West University \\ fkakwata@gmail.com
}

\begin{abstract}
This article attempts to analyse and evaluate strategies for overcoming sin in relation to poverty in the African context. However, to address sin in this context means eliminating the very causes that give rise to the social malady. It is argued that the classical strategies (regeneration, reform and revolution) used thus far to address the issue of social sin, seem unable to deal with all its causes. This article proposes an alternative strategy based on the three offices of Christ, namely prophetic, priestly and royal, for a relevant approach to the issue of sin in poverty-related contexts within an African environment.
\end{abstract}

Key words

Strategies; poverty; sin; evil structures; offices of Christ

\section{Introduction}

Previous studies have established an inevitable relationship between sin and poverty and this connection is well understood in the context of commissioned love for one's neighbour (Myers 2007:86, 118-119; Wyngaard 2013:244). Human beings were created to live in relationship with God, others and nature, based on love. Sin is the detrimental element that destroys the image of God in humans and severs the mentioned fundamental human relationships. Such broken relationships clearly indicate that love is in crisis. Sin may be seen as a lovelessness, which is an ultimate factor contributing to poverty in society (Wyngaard 2013:218-230).

In recent years, the issue of poverty has received considerable attention amongst academics, policy makers and theologians. Experts have developed different theories in an attempt to explain the causes of poverty and have proposed measures to remedy this deficiency. In general, non-government 
organisations (NGOs) and churches have done well in delivering basic social services such as feeding the hungry, providing health care, or education, all in an effort to alleviate abject poverty. However, the reality is that poverty remains widespread in Africa, where the sub-Saharan region is affected the most. The latest available estimates indicate that almost half of the population of sub-Saharan Africa, that is to say $48 \%$, live in poverty (Arndt, McKay \& Tarp 2016:7). In this light the researcher found that there are limited interventions to address poverty-related sin that has become entrenched in the larger socio-economic context.

In this article, the researcher utilises the tool of practical theology to analyse and evaluate strategies which help people deal with sin in a poverty-related context. The article also formulates an alternative strategy that can help the churches in Africa approach the issue of sin in the context of poverty more effectively. The research questions were: What approach can be followed to deal with the issue of sin-related poverty in order to facilitate the transformation of society to a state of well-being? How can the church help transform a surrounding society in which the strongholds of poverty, injustice and corruption are firmly established?

\section{The concept of sin}

The phenomenon of 'sin' can be defined as a disordered or disrupted relationship toward God; it also implies wrongful actions or deeds affecting one's fellow humans (McFarland 2011:473). Similarly, König in De Gruchy and Villa-Vicencio (1994:109) states that to sin 'is to live either in wrong or in broken relationships'. This implies that human beings are made to live in relationships with God, others and the environment, based on love. The absence of this Christian relational dynamic ipso facto disrupts these relationships and in the context of poverty relationships it might lead to the oppression, exploitation and injustice of humans by their fellow human beings. It is clear that sin is the harmful element that destroys the abovementioned basic relationships. In this regard sin implies the failure to love God fully and one's neighbour unconditionally, which is synonymous with lovelessness. This is one way through which poverty gains a foothold in society. At this point the relationship between sin and poverty can be perceived clearly. 
As noted above, the reality of $\sin$ is that it can be personal or communal. Regarding the collective form of sin, various terms are used to designate this social phenomenon and each term portrays a particular emphasis. For example, the sin of the world which is one of the phrases used to designate social sin, is understood as 'a sin that runs through time and space infecting both persons and institutions' (Blair, 2007:4). The concept of sinsolidarity reveals the incorporation of all humans into the original sin and the incarnation of sin in the world (O'Keefe 1990:27). The term social sin is used most commonly to denote sin as a social phenomenon. O'Keefe understands social sin as follows:

- Structures that oppress human beings, violate human dignity, stifle freedom, and impose gross inequality.

- Situations that promote and facilitate individual acts of selfishness.

- The complicity or silent acquiescence of persons who do not take responsibility for the evil being done.

Thus, social sins can be understood as those committed against society or against the common good, and thus also referred to as social injustice. Examples are: slavery, corruption, misuse of public funds, oppression and exploitation.

The Old and the New Testaments testifies to the fact that sin is a social reality in the world in which humans live. These narratives also substantiate the notion of a social dimension of sin that reaches beyond individualistic transgressions. One can observe that certain specific social sins, as mentioned above, do cause and sustain poverty in society. These forms can be identified in many illicit acts of government, political and economic structures, and in destructive activities such as corruption, oppression, exploitation, human rights violations, discrimination, injustice, racism or imperialism (Kakwata 2016:4).

From this perspective, a close link can be pointed out between social ills and sin related to poverty. In other words, social injustice influences poverty systems in a given society. Myers (2007:88) in his book Walking with the poor, echoes this view when he identifies sin as the fundamental cause of poverty. For him the reason is that sin implies the root cause of deception, distortion and domination. He insists that, in instances where people do not treat each other well, this is because God does not form the centre of 
their story. Thus, for the African society to experience transformation from poverty to a state of well-being there is a need to address sin that is rooted in the social structures.

\section{The concept of poverty}

Poverty as concept has been defined in different ways, thus there is no a single universally agreed definition of this phenomenon. Yet from the perspective of the economy, poverty can be understood as a situation of material deprivation, or lack of money/means to lead a decent life (Odekon 2006:261). Two types of poverty can be distinguished in this regard: case and community poverty. Case poverty refers to societies that are more prosperous and where only certain individuals or families are poor. Community poverty, as the word suggests, indicates a society in which almost everyone lives in poverty (August, 1999:15). This is what most development researchers call mass poverty and is the harsh reality in several parts of Africa.

It should also be noted that all people are not poor to the same degree. The level of poverty varies between individuals, communities and countries. In this regard, poverty can be classified as absolute or relative (Swanepoel \& De Beer 2007:2). The former describes poverty in terms of basic needs such as food, clothing, and housing (Odekon 2006:261), while the latter refers to people whose basic needs are met, but they are still experiencing disadvantages as compared to other people or groups of people (Swanepoel 2007:3).

One of the largest problems of the above-mentioned chronic poverty is the unfair distribution of wealth. Crook (2013:271) describes such distribution as a complex problem in the sense that it does not only concern inequality in income (where many people are rarely remunerated based on what they deserve). According to Crook, the unfair distribution of wealth goes beyond the matter of wages; it also entails the accumulation of immense wealth by a relatively small number of people and legal entities. Therefore, wealthy people ipso facto are inclined to control the lives of others (Crook 2013:271). This situation can lead to the oppression and exploitation of the masses and the impoverishment of many. 
This was one of the main factors that caused and perpetuated poverty in the ancient Mediterranean world where wealth was determined by the ownership of land. However, most land was concentrated in the hands of a small group. This condition resulted in a systematic exploitation of the poor (Kakwata 2015:3). For example, the passage in Nehemiah 5:1-5 explains how landownership became a tool of exploitation in the post-exilic period in Israel. This situation can be attributed to the lack of love as identified by liberation theologians such as Gutiérrez (1974:295) in the following words: "Poverty is an expression of a sin, that is, of a negation of love. It is therefore incompatible with the coming of the Kingdom of God, a Kingdom of love and justice." Jesus Himself said that the greatest commandment has two sides: to love God and to prioritise the interests of one's neighbour ( $\mathrm{Mt}$ 22:36-40).

Before investigating strategies for overcoming poverty-related sin, it is necessary to analyse the causes or circumstances that lead people to commit sin. The reason is that people's response to sin depends largely on their understanding of the causes of this condition.

\section{Causes of sin in a poverty-related context}

Sin is a highly serious issue in the contemporary world; it affects the lives of individuals and society as a whole. Erickson $(2013: 517,584)$ expressly highlights three possible causes that can lead people to commit sin or the 'predisposing factors that give rise to sin', namely ignorance, inattention, and error. This applies individually as well as on a collective level.

\section{Ignorance}

Ignorance is considered as one of the causes that can lead people to commit sin. The Hebrew Bible uses two synonyms, שגה (shagah) and שגז (shagag), to express the idea of ignorance, which basically means to err or diverge (Erickson 2013:517). Its equivalent in the Greek New Testament is á $\gamma v o \varepsilon \dot{\varepsilon} \omega$ (agnoeō), which has the meaning of not to know, to be ignorant (Verbrugge 2000:11). The same source states that the Stoics went as far as to regard ignorance as the root of all evil. This is because a lack of knowledge causes an individual or a community to make more mistakes. The ignorance in question implies that, either the person has not received the knowledge, 
or simply has rejected it (Verbrugge 2000:11). In this regard the Bible emphasises two types of ignorance: innocent (unconscious, unintended) and culpable (consciously intended). It should be mentioned that in many instances where the word á $\gamma v o \varepsilon \dot{c} \omega$ appears, it does denote innocent ignorance. This is evident from phrases such as, 'I do not want you to be unaware' in Romans 1:13; 11:25; 1 Corinthians 10:1; 12:1; 2 Corinthians $10: 1$, and in many other passages. According to the Scriptures, God also did overlook certain sins that people committed in ignorance (Acts 17:30).

However, it appears that in certain instances the ignorant actions of individuals are culpable and intended. For example, according to the exegesis, the Apostle Paul explains that the Ephesians as prior heathens were darkened in their understanding and excluded from the life of God because of the ignorance remaining in them (Eph 4:18). This type of ignorance is not innocent because it stems from the hardness of people's heart. This entails a deliberate refusal to take into consideration the truth that comes from the Word of God - an attitude that may lead to further sinning.

\section{Inattention}

Inattention is another cause for sin as depicted by the biblical narratives.

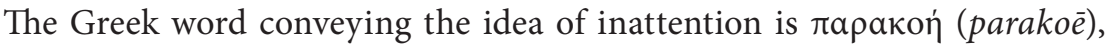

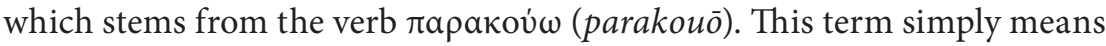
failing to hear, taking no heed or paying no attention, therefore, таракопं also denotes disobedience (Verbrugge 2000:29). In the New Testament the word rapakon (Heb 2:2-3) is used in the sense of disobedience that stems from inattention (Erickson, 2013:519). In the biblical tradition hearing plays an important role. As Verbrugge (2000:29) specifies, 'God meets human beings through his Word,' and people are commanded to hear God's words. Expressions such as "hear, O Israel” (Deut 6:4); "listen, O heavens, and hear, O earth, for the Lord speaks" (Isa 1:2) warn people, nations, earth and heaven that they should listen to the Word of God.

However, in several cases people failed to be obedient to the truth after hearing God's words and yet not listening. This results in the hardening of hearts and leads to sin. For example, Isaiah 1:2-4 explains how Israel failed to pay attention to the Word of God. They then degenerated into a sinful nation where evil prevailed; practicing injustice and oppressing the orphan and the widow (Isa 1:17). 


\section{Error}

The biblical testimony underlines another cause of sin as 'error'. This term can be understood as the human inclination to go astray or make mistakes (Erickson, 2013:517). This is portrayed in the Hebrew word תעה (ta'ah), which basically means to wander about, stray from God's commandment, stagger, to sway, or to reel (Botterweck \& Ringgren 2006:733-734). Unlike the two synonyms שגה (shagah) and (shagag) that refer to unwitting mistakes, תעה (ta'ah) expresses a deliberate transgression or a conscious decision against God's Law (Ibid. 735). The usage of the word תעה is frequent in the Old Testament. For example, Isaiah 32:6 applies the word in the following sense:

For a fool speaks nonsense, and his heart inclines toward wickedness, to practice ungodliness and to speak error against the Lord, to keep the hungry person unsatisfied and to withhold drink from the thirsty.

In this context, the word 'error' represents a sinful behaviour, which resulted in keeping the needy persons destitute. Another example is found in Ezekiel 44:10 where the prophet is blaming the Levites for having gone astray. Botterweck and Ringgren (2006:735) mention agents such as false prophets or unfaithful kings that mislead God's people.

In the New Testament, the Greek word portraying sin as error, is $\pi \lambda \alpha v \alpha$ o $\mu \alpha$ । (planōmai) the passive form of $\pi \lambda \alpha v a \dot{\omega}$ (planaō), which means to lead astray, cause to wander, mislead by one's behaviour and words (Verbrugge 2000:466). Erickson (2013:518) emphasises that the cause of being led astray is deception, but which can be avoided as the statements attest to: for example, "See to it that no one misleads you" (cf. Mark 13:5-6) or "Do not be deceived" (1 Cor 6:9). The New Testament emphasises three possible sources of errors or deceptions, namely false teachers (2 Pet 2:1), oneself (1 Cor 3:18; Jas 1:22; 1 John 1:8) and evils spirits (1 Tim 4:1, Rev 12:9). A specific example of ignorance, inattention and error, which causes poverty within an African setting, can be found in corruption.

Recent studies reveal that corruption is widespread in Africa and has contributed enormously to the rise of poverty in the continent (Ignatius, 2009:638). Corruption as a concept does not have a universally accepted definition. However, Anne (2016:104) a lecturer in Pastoral Theology/ 
Spirituality department at Catholic Institute of West Africa, describes corruption as any form of unethical behaviour linked to a particular motivation, namely that of private gain at public expense. Anne indicates that the corrupt behaviour in question entails violating the established rules for personal gain. She explains that corruption is practiced in different forms such as smuggling, fraud, illegal payments, money laundering, or tax evasion.

Africa comprises highly religious peoples. Each religion has norms, and values contained in its doctrine that are supposed to promote social control and acceptable standards in society, thus reducing vices such as corruption (Adebimpe \& Ayodeji 2014:1). For example, with regard to Christian religion, the Scripture gives clear instructions about corruption and bribe. Exodus 23:8 stipulates: 'And you shall not take a bribe, for a bribe blinds the clear-sighted and subverts the cause of the just'; Ecclesiastes 7:7 warns: 'For oppression makes a wise man mad, and a bribe corrupts the heart'.

Furthermore, in most African nations the government has established laws and regulations to curb corrupt activities - laws that are informed by the United Nations Convention against corruption. The prevalence of corruption in Africa suggests that people have failed to follow the religions norms and values regarding this malady and the laws governing it. This might be due to people's ignorance or unawareness of those values or a deliberate rejection of such norms, or again, the tendency to error. The sources of error in this context could be as Erickson (2013:517) points out: humans can influence their fellow human beings to practice corruption or people can deceive themselves to fall into such a mistake.

Having explored possible causes leading to sin, the following section analysis and evaluates of certain strategies to overcome sin in a povertyrelated context.

\section{Analysis of strategies to overcome poverty-related sin}

In an earlier article ${ }^{1}$ the researcher dealt with a theology of sin related to poverty. However, strategies that help address sin in the context of poverty

1 Kakwata, F, 2016. A theology of sin related to poverty. In die Skriflig. http://dx.doi. org/10.4102/ids.v50i1.2033. 
were not examined. Thus, these approaches need to focus on eliminating the very causes that give rise to those particular sins. In this regard the different strategies that can be used are explicated below.

\section{Regeneration}

The concept of regeneration derives from the Greek word $\pi \alpha \lambda \iota \gamma \gamma \varepsilon v \varepsilon \sigma i \alpha$ (palingenesia) that is made up of two word stems, palin (again) and genesis (birth, origin), and means rebirth or renewal of life (Verbrugge 2000:430). In the secular Greek, the word $\pi \alpha \lambda ı \gamma \gamma \varepsilon v \varepsilon \sigma$ ia means 'a return to a former state of existence' (Comfort \& Elwell 2001:1116). According to the biblical perspective, the word $\pi \alpha \lambda \iota \gamma \gamma \varepsilon v \varepsilon \sigma i \alpha$ refers to different types of renewal, for example, 'the return or restoration of something, termination of captivity, restoration to health following a birth or illness' (Verbrugge, 2000:430). The word $\pi \alpha \lambda \mathrm{\iota} \gamma \gamma \varepsilon v \varepsilon \sigma i a$ appears only twice in the New Testament, for example in Matthew 19:28 where it refers to 'the renewal of all things when the son of man sits on his glorious throne' (Ibid. 430). The renewal in question occurs at individual as well as national level. In this sense, Allison (2011:474) defines regeneration as 'a secret act of God in which he impacts new spiritual life to us. This is sometimes called being born again (using language from John 3:3-8)' or conversion. Thus, the strategy of regeneration is considered as the classic approach to overcome sin, in this case sin in a poverty-related context.

This approach strives to restore human dignity and realise God's purpose in society through spiritual renewal. The standpoint is that if people in a given society are changed, the whole society will be transformed as well (Erickson, 2013:597). This does not mean that the agents will change the society directly; on the contrary, they will focus on evangelism. This is done in the hope that as people progressively become Christians the society as a whole will be changed as well. This notion is expressed in the slogan by Maggay (1994:16): 'Change people, change society'. This expression observes that the presence of a large number of Christians does not necessarily guarantee a better society. As example, this scholar points out that most members of the ruling class in South Africa during the apartheid era were Christians from the Dutch Reformed Church. Personal regeneration of individuals is one way to correct the evils in society. But it is vital to remember that even if individuals become Christians, there is a 
clear possibility that they will continue living according to the principles of their society.

For example, it is estimated that more than $90 \%$ of the population in the Democratic Republic of the Congo (DRC) is Christian, but the country is ranked amongst the most corrupt nations in Africa and in the world (Ekakhol 2009:240). Allegedly corruption has become the normal way of life in the country and it seems to be irreversible, because there is no mechanism in place to uproot this plague. Zambia was declared a Christian nation in December 1991 (Phiri, 2003:401) by the late president Chiluba. Sadly, during president Chiluba's rule, corruption was identified as a feature of public life in Zambia (Momba 2007:116).

These examples sufficiently dismiss the assumption that the more Christians there are, the more just the society will be. In light of the information above, the following section examines reform as a strategy to correct $\sin$ in a poverty-related context.

\section{Reforming social structures}

The concept 'reform' implies 'change that is made to social system, an organisation, etc. in order to improve or correct it' (Hornby 2010:1236). Thus, the reform approach or strategy of reform advocates changing the evil structures of society that give rise to and sustain poverty. Several possibilities are suggested for altering the structures of society. An example is amending the political form of society through political channels, or restructuring society by electing lawmakers who will change society by passing laws to reform the social structures (Erickson, 2013:598). It is believed that when such laws are enforced it can help change the conditions in the society and facilitate transformation.

In this regard, Erickson (2013:598) makes a pertinent observation that there is no guarantee that if the structure is altered the individuals within it will necessarily also be changed. It could be argued this is what is taking place in Africa and particularly in South Africa currently. Since the 1990s a wind of perestroika swept across the world and brought an end to the Cold War, followed by dramatic political changes throughout the African continent. There was a worldwide rejection of military dictatorships and reigns of terror that oppressed and impoverished large groups of people (cf. 
Nest, Grignon \& Kisangani 2006:24). African nations were encouraged to embrace the policy of multiparty democracy.

As it happened, the change of the society through political reform did not necessarily correct social sins embedded in the larger socio-economic structure in several African societies. As a result, after more than two decades of democracy, poverty is still widespread on the African continent, particularly in the Sub-Saharan region. Wyngaard (2013:ii) points out that, since 1994 and the democratic transition, South Africa has made enormous progress in improving the quality of its citizens' life. But he indicates that a significant number of people still live in abject poverty. This suggests that the alteration of the social structure does not necessarily eliminate the root causes of sin (ignorance, inattention and error) in a poverty-related context. Therefore, some consider more incisive measures such as socioeconomic revolution, a strategy which will be analysed subsequently.

\section{Revolution}

Revolution is a fairly recent concept in politics, and was introduced in the late $17^{\text {th }}$ and $18^{\text {th }}$ centuries to designate constitutional and political change. According to its modern use, revolution denotes mass movement and the overthrow of the social, economic and political systems (Fahlbusch, Lochman, Mbiti, Pelikan \& Vischer 2008:685). In the same vein, Chatterjee (2011:31) views revolution as 'protracted events of conflict between groups or classes often involved violence and lead to social and political transformation'. Thus, revolution entails an extreme approach that can be applied to alter the evil structures of society. The process aims to bring about change by using force if necessary in case the social structures are considered too corrupt for reform to accomplish real change (Erickson, 2013:598). This radical strategy has been used extensively in the past to bring about change by replacing existing oppressive structures forcefully with the envisaged new ones. For example, one can refer to the Ghanian revolution by Jerry Rawlings in 1979, and the Iranian revolution also known as the Islamic revolution in 1979 (Lafraie, 2009:1), to mention but a few.

Christians disagree sharply whether revolution can be a legitimate strategy to correct social sin that is accountable for the ongoing cycle of poverty in society. For example, Rodney (2012:287) insists that revolution is the only way to free society from the evil system responsible for all the past 
and present misery. In contrast, certain Christians view the church as an anti-revolutionary force and consider revolution as an extreme antithesis of Christianity, and human-centred rather than divine (Fahlbusch et al. 2008:688).

Other Christians take a different view of revolution by assuming that the church deprived itself of the right of revolution but tolerated and witnessed passively as the consolidation of absolute dictatorial regimes took place. For this reason, in Geneva in 1966, the Church and Society Study Conference of the World Council of Churches initiated a discussion on a theology of revolution in order to determine the Christian ethics of change (Yoder, Koontz \& Alexis-Baker 2009:375). No agreement was reached, seeing that the participants defined revolution differently. For example, according to Yoder et al., the Russians posited that the whole world needs revolution; the Europeans emphasised that the Industrial Revolution was more important than regime change; the delegates from developing countries thought in terms of liberation in Latin America and the African national movements.

As noted above, the problem with revolution is that in most cases it leads to violence. Most Christians believe that violence should not be an option to correct social error in a poverty- related context. These believers rely on Romans 12:17-21 to advocate non-violence in order to bring about social change (Chan, 2001:180). In brief, this implies that we are not to fight evil with evil but we are to overcome wickedness with our good actions.

\section{Concluding remarks}

In the light of the discussion above, strategies for overcoming sin in relation to poverty consist of negating the very causes that give rise to those particular sins. The predisposing factors that lead to sin at the individual as well as collective level were found to be: ignorance, inattention, and error. It became clear that the three classical strategies namely regeneration, reform and revolution, used thus far to address the issue of sin in relation to poverty, seem unable to deal with all its causes efficiently.

For example, the strategy of regeneration holds that the more Christians there are, the more just the society will be. However, experience has taught that the strategy of regeneration failed to eliminate the mentioned predisposing factors that give rise to and help sustain structural sin in 
society. Naturally personal regeneration is a applicable beginning to address sin related to poverty, but as such is not sufficient. Conversion of individuals through the action of the Holy Spirit places them in a prime position to contribute to the change of society.

The reform of social structures and revolution appear to be helpful to remove the structures that is deemed too evil. History indicates that such strategies have produced concrete results. However, they do not deal with the causes of sin that are rooted in the structures and are responsible of the ongoing cycle of poverty. Thus, these approaches need to focus on eliminating the causes that give rise to those particular sins.

After examining different approaches to deal with sin in the context of poverty, the following section investigates the threefold offices of the church to propose an alternative strategy.

\section{The paradigm of the three offices of Christ}

The central research question was: Which pragmatic approach can be followed to deal with sin-related poverty in order to facilitate the transformation of society to a state of well-being? This article proposes the three offices of Christ as an applicable paradigm. The concept 'office', as Fahlbusch et al. (2008:820) specify, derives from Latin officium which means office, duty; it denotes an ecclesiastical office or a ministry. These scholars clarify that the term office refers to 'a divinely or ecclesiastically ordained ministry and the acceptance of a spiritual mission'. According to Christian tradition, the work of Christ is defined in terms of offices that normally are understood as threefold: prophetic, priestly and royal (Breshears, 1994:5). The nature of Christ's messianic office implies mediatorial work between God and humans, as the Scriptures testify (1 Tim. 2:5) and finds its background in the Old Testament.

During the period of the Old Testament, the rulership of Israel was characterised by three distinct major offices with a specific function attributed to each. For example, the function of the prophetic office consisted of proclaiming God's Word to the people; the priestly office entailed offering sacrifices, prayers and praises to God on behalf of the people; and the royal office was commissioned to rule the people in the 
name and authority of Yahweh (Grudem 1994:624). It is believed that these three offices signified Christ's redemptive work, in other words, the mission of Jesus on earth embodied the three mentioned offices. These offices find their fulfilment within the framework of the kingdom of God.

Grudem (1994:624) explains the threefold office as follows:

- As Prophet, Christ revealed and spoke God's words to humanity.

- As Priest he offered Himself as sacrifice to God for humankind's sins.

- As King he rules over the church and the whole world.

Accordingly, the church shares these threefold messianic offices of prophet, priest, and king. This is because the church is understood as the body of Christ, a community of spirit-led people called to continue Jesus' mission. Essentially, God's overall plan for the church in this age finds its roots ultimately in the mission and message of Jesus that announced the coming of the kingdom of God, which is a good news to the poor.

The following subsection investigates the three offices (prophetic, priestly and royal) of the church as an alternative strategy to deal with sin in relation to poverty, in order to help bring about positive change in society.

\section{The prophetic role}

The prophetic role of the church is in essence to proclaim the Word of God to humanity. According to Grudem (1994:28), whenever the church communicates the truth of the Word of God to the world it executes its prophetic function in the broad sense of the word. As mentioned above, one of the causes of sin identified particularly in the context of poverty, is ignorance. However, the strategy to dealing with such sin is to address the causes that give rise to this evil. In such a case a teaching or a prophetic word is needed from the church to help remedy this deficiency.

The problem is that the prophetic word is not always welcome since the truth can hurt and people sometimes detest hearing it. This is where the sin of inattention enters the fray. Below are a few examples of prophetic words that challenged the powers of the day:

- For 30 years Jeremiah prophesised the imminent destruction of Jerusalem and the Babylonian exile because people disobeyed the words of God and rejected God's Law (Jer 6:1-30). 
- Elijah predicted drought in Israel during the reign of King Ahab due to his idolatry (1 Kings 17:1).

- The prophet Nathan reprimanded King David for his adultery with Bathsheba the wife of the murdered Uriah (2 Sam 12).

- Jesus rebuked the Pharisees for ignoring the Law of God and substituting it with the tradition of men (Mk 7:8).

The examples above can inspire the church, particularly congregations in sub-Saharan Africa. It can point out new ways to speak out prophetically against the strongholds of corruption, oppression, exploitation and social injustices that contribute to the on-going cycle of poverty in Africa. Currently these distortions and social imbalances persist, particularly in sub-Saharan Africa contexts that are predominantly Christian. For that reason, the church needs to proclaim a prophetic word that can transform and liberate the larger African society from the grip of, for example, povertyrelated sins rooted in the social structures and the wider dimension of evil as well.

Breshears (1994:20) rightly argues that the church's weakness is due to the fact that it was not established to instigate change in a sinful world. Thus, the church has to counter the evil and ignorance that are overtaking the biblical principles and establishing a secular agenda, which lead to sins. In this context, the focus is on sins related to poverty in the sub-Saharan Africa society. Furthermore, the church has to fulfil its prophetic role effectively by pronouncing a moral vision of society based on the values of the kingdom of God (where God's dominion holds sway), interacting through a godly character and proclaiming God's truth.

\section{The priesthood office}

The church's priesthood office implies mediation between God and humans. According to Maggay (1994:71), the priestly role of the church is about 'bringing the need of the world to God and the power of God to the world'. Through intercession the church can accomplish its sacerdotal function, and thereby continue Christ's ministry of mediation. Jesus himself set an example of intercessory prayer. For instance, He prayed for the unity of his followers (John 17:20-26). On the cross Jesus prayed for his persecutors to be forgiven (Luke 23:34). Accordingly, to accomplish its priestly function the church is called to pray consistently for a wide range 
of realities: the world, the government, community, neighbourhood, and families' needs in general, the welfare of society and for the spreading of the Gospel. The church has to pray against the power of sin that gives rise to injustice, oppression, exploitation, and corruption, which ultimately leads to poverty. In doing so, the church will help heal the social wounds of the African society and facilitate social transformation.

Unfortunately, reality indicates that not many prayers from the current church are directed to poverty-related sin rooted in the social structures. De Klerk (2005:243) in his article 'Worship, prayer and poverty', makes the same observation as in numerous books written on poverty. He finds that the power of prayer in worshipping services is rarely emphasised as the initial strategy to deal with poverty. It is important that congregations consider unremitting prayer - an integral part of its priesthood function - as a strategy to address sin in relation to poverty and human suffering in their worshipping services.

\section{The kingly office}

The kingly office of Christ entails his dominion over and the governance of all things in heaven and on earth, according to the Scriptures (Matt 28:18). The church is, therefore, seen as reigning with Christ (Rev 20:4), not in the sense of occupying a position of authority, but in terms of a servanthood rule, a dominion under the authority and the power of the living Christ (Maggay 1994:72). This dominion was afforded human beings at the beginning of creation when God blessed Adam and Eve saying: "Be fruitful and multiply, and fill the earth, and subdue it, and rule over the fish of the see and over the birds of the sky, and over every living thing that moves on the earth" (Gen 1:28). It happened that this dominion was lost due to the fall of humans as Genesis 3 indicates, "and now restored to us in Jesus" (Ibid. 72). Luke 22:26 confirms the restoration of the authority and specify that it should be exercised in a "servanthood" manner.

According to this perspective, Maggay (1994:72) describes the church as the servant to society. Thus, the royal office of the church can be a significant strategy to address wickedness as the cause of sin in relation to poverty, and many other evils in the African society. In this sense, Elliston (1989:145) understands Christianity as one of "the strongest, most powerful social forces affecting social transformation"”. 
As noted previously, the classical strategies, namely regeneration, reform and revolution applied thus far to correct the issue of social sin, seem insufficient to deal with all its causes. This is because these approaches often change the external circumstances but do not reach the root causes of sin entrenched in the structures. In addition, the essence of sin as such is fundamentally spiritual, therefore, it requires specific approaches to invalidate the factors that give rise to sin and ultimately lead to poverty.

The researcher believes that if the church in Africa understood its mandate in the context of the kingdom of God and effectively exercised its prophetic, priesthood and royal offices it can help bring about positive change in the society. For instance, as noted above, the prophetic message of the church can help address ignorance. The priestly office can remedy inattention that lead people to commit sin. In the practice of its sacerdotal function as De Klerk (2005:353) explains, the church should identify with the sins of society or a nation like Daniel 9:1-19 and Nehemiah 1:5-7 who identified with the sins of their people and confessed those transgressions as if it were their own. De Klerk argues that God punishes sin in general - the sins of both the poor and of their oppressors. For that reason, he suggests that the church should plead to the Holy Spirit to awaken repentance in people's hearts for the sinful behaviour within the church and the nation as a whole. It should be remembered that inattention as one of the predisposing factors that give rise to $\sin$.

Finally, the kingly office can help the church tackle and overcome errors. The source of errors, as already explained, are evil spirits, humans who lead others into errors, or humans who deceive themselves. Thus, the church needs to identify the source that drive people into errors within the church and in the society. Thereafter the church should exercise authority in the power of the living God by ruling over the obstinate forces that seek to destroy God's world. These are the maladies such as corruptions, egotism, power grabbing and greed/avarice, even other evils arising from a mismanaged and disordered society. However, only in the new world and existence eternally with God, the church will experience the complete absence of sin and the fullness of prosperity, which is, therefore, still eschatological. 


\section{Conclusion}

The purpose of this article was to analyse and evaluate strategies to deal with sin in the context of poverty relationships. It has been noted that sin is not only confined to the individual level, it manifests in the social structures as well. Thus a close link was pointed out between social ills and sin related to poverty. The problem is that social sin, and particularly in a poverty-related context, is difficult to identify and combat. However, recognising sin in relation to poverty is indispensable because it affects one's understanding of the causes of poverty and inspires one's response. The article reiterated that $\sin$ in relation to poverty is widespread in the African contemporary society and manifests itself in the forms of individual and social sin.

Strategies to correct $\sin$ focus on invalidating the causes that give rise to this evil. Views are varied regarding the appropriate approach to deal with sin in a poverty-related context. Most Christians reject revolution as a strategy to correct social sin. They do not view it as an option for Christians, since in most cases it causes violence and violates biblical principles.

Due to the complicity of sin in poverty-related contexts, the use of a single strategy might not be sufficient to deal with all the causes of such sin. This requires a combination of different strategies, in this case, regeneration and reform. Applying the strategies of regeneration and reform could be an appropriate start to address the issue of sin in the mentioned context. However, these interventions are not sufficient to eliminate the causes of $\sin$. Therefore, they have to be complemented by the strategy based on the three offices of the church, namely prophetic, sacerdotal and royal. This is crucial in order to facilitate the transformation of the degenerate social structures and help uplift the poor and destitute towards a standard of well-being that is measured within the African contemporary society.

\section{Reference list}

Adebimpe, AA \& Ayodeji, OS 2014. Religious values and corruption in Nigeria-a dislocated relationship, Journal of Educational and Social Research. [Online]. Available: https://www.google.co.za/serch/?q=corr uption+in+traditional+religion $=$ GWKAWPGuG4XBgAaf7rawDA\&st $\operatorname{art}=10 \& \mathrm{sa}=\mathrm{N} \& \mathrm{biw}=1366 \& \mathrm{bih}=659$. [Accessed 19 January 2017]. 
Allison, GR 2011. An introduction to Christian doctrine: a companion to Wayne Grudem's systematic theology. Grand Rapids: MI, Zondervan.

Anne, MM 2016. The role of the church in eradicating corruption and enhancing development and unity in Africa. AFER. [Online]. Available: http://nwulib.nwu.ac.za/login?url=http://search.ebscohost. com/login.aspx?direct=true $\& \mathrm{db}=\mathrm{rfh} \& \mathrm{AN}=\mathrm{ATLAn} 3886465$. [Accessed 18 January 2017].

Arndt, C McKay, A \& Tarp, F 2016. Growth and Poverty in Sub-Saharan Africa. Oxford: Oxford University Press.

August, K Th 1999. A Curriculum for Community Development in Practical Theology. Unpublished master's thesis. Stellenbosch: Stellenbosch University.

Blair, T. 2007. Sin of the World. America. [Online]. Available: http:// nwulib.ac.za/login?url=http://search.ebscort.com/login.aspx?direct=tr $\mathrm{ue} \& \mathrm{db}=\mathrm{aph} \& \mathrm{AN}=24625285$. [Accessed 5 February 2016].

Botterweck, GJ \& Ringgren, H 2006. Theological dictionary of the Old Testament. Grand Rapids, MI: Eerdmans.

Breshears, G 1994. The body of Christ: prophet, priest, or king? JETS. [Online]. Available: http://www.etsjets.org/files/JETS-PDFs/37/37-1/ JETS_37-1_003-026_Breshears.pdf. [Accessed 03 January 2016].

Chan, S 2001. THE1042 Man and sin. An independent study textbook. $2^{\text {nd }}$ ed. Study guide, Global University.

Chatterjee, DK 2011. Encyclopedia of global justice. Dordrecht: Springer.

Comfort, PW \& Elwell, WA 2001. Tyndale Bible dictionary. Carol Stream, Ill: Tyndale.

Crook, RH 2013. An introduction to Christian ethics. Boston: Pearson.

De Klerk, BJ 2005. Worship, prayer, and poverty. Ecumenical review. [Online]. Available: http://search.ebscohost.com/login.aspx?direct=tr $\mathrm{ue} \& \mathrm{db}=\mathrm{AN}=\mathrm{ATLA} 0001516082 \mathrm{site}=$ ehost-live\&scope $=$ site. [Accessed 19 October 2015]. 
Ekakhol, EB 2009. Justice and poverty in the Democratic Republic of the Congo: a challenge to the church. Unpublished doctoral dissertation. Pretoria: University of South Africa.

Elliston, EJ 1989. Christian relief and development. Dallas: Word publishing.

Erickson, M 2013. Christian theology, $3^{\text {rd }}$ ed. Grand Rapids, MI: Baker Academic.

Fahlbusch, E, Lochman, JM, Mbiti, J, Pelikan, J \& Vischer, L (eds). 2008. The encyclopedia of Christianity. Grand Rapids, MI: Wm. B. Eerdmans.

Grudem, W 1994. Systematic theology: an introduction to biblical doctrine. Leicester: Inter-Varsity Press.

Hornby, AS 2010. Oxford advanced learner's dictionary of current English. Oxford: Oxford University Press.

Gutiérrez, G 1974. A theology of liberation: history, politics and salvation. London: SCM Press.

Ignatius, E 2009. The Church and Corruption in Africa. AFER. [Online]. Available: http://nwulib.nwu.ac.za/login?url=http://search.ebscohost. com/login.aspx?direct=true $\& \mathrm{db}=\mathrm{rfh} \& \mathrm{AN}=\mathrm{ATLA} 0001758513$. [Accessed 18 January 2017].

Kakwata, F 2015. An inquiry into socio-historical factors contributing to poverty within the Early Church in Palestine. In die Skriflig. [Online]. Available: http://dx.doi.org/10.4102/ids.v49i1.1993. [Accessed 31 January 2016].

- 2016. A theology of sin related to poverty. In die Skriflig. [Online]. Available: http://dx.doi.org/10.4102/ids.v50i1.2033. [Accessed 17 January 2017].

König, A 1994. The broken human image of God. In J.W. De Gruchy \& C.Villa-Vicencio, (eds.). Doing theology in context: South African perspectives. Maryknoll, NY: Orbis. 102-112. 
Lafraie, N 2009. Revolutionary ideology and Islamic militancy: The Iranian Revolution and Interpretations of the Quran. London: Tauris Academic Studies.

Lincoln, A 1990. Word biblical commentary. Dallas: TX, Words.

Maggay, M 1994. Transforming society. London: Regnum.

Momba, J 2007: The intersection between politics and corruption in Zambia, South African Journal of International Affairs. [Online]. Available: http://nwulib.nwu.ac.za/login?url=http://search.ebscohost. com/login. aspx?direct $=$ true $\& \mathrm{db}=$ eoah\&AN=20269261. [Accessed 30 December 2015].

McFarland, IA 2011. The Cambridge dictionary of Christian theology. Cambridge: Cambridge University Press.

Myers, BL 2007. Walking with the poor: principles and practices of transformational development. Maryknoll, N.Y: Orbis.

Nest, M, Grignon, F \& Kisangani, EF 2006. The Democratic Republic of the Congo. Economy dimensions of war and peace. London: Lynne Reinner.

Odekon, M 2006. Encyclopedia of world poverty. Thousand Oaks: CA, Sage.

O'Keefe, M 1990. What are they saying about social sin? New York, NY: Paulist Press.

Phiri, IA 2003. President Frederick j.t. Chiluba of Zambia: the Christian nation and democracy. Journal of religion in Africa. [Online]. Available: http://nwulib.nwu.ac.za/login?url=http://search.ebscohost. com/login.aspx?direct $=$ true $\& d b=a p h \& A N=12408242$. [Accessed 30 December 2015].

Rodney, W 2012. How Europe underdeveloped Africa. New York, NY: Black Classic Press.

Swanepoel, H \& De Beer, H 2007. Community development: breaking the cycle of poverty. Lansdowne, South Africa: Juta. 
Verbrugge, VD 2000. New international dictionary of the New Testament theology. Grand Rapids, MI: Zondervan.

Wyngaard, JG 2013. In search of root causes of poverty testing a theological perspective in development dialogues. Unpublished doctoral dissertation. Stellenbosch: University of Stellenbosch.

Yoder, JH Koontz, TJ \& Alexis-Baker, A 2009. Christian attitudes to war peace and revolution. Grand Rapids, MI: Brazos Press. 